DOI: $10.19195 / 2084-5065.48 .6$

\title{
Populacja więzienna w Polsce po nowelizacji systemu prawa karnego ustawą z 20 lutego 2015 roku
}

\author{
ALDONA NAWÓJ-ŚLESZYŃSKI \\ Zakład Prawa Karnego Wykonawczego \\ Wydział Prawa i Administracji Uniwersytetu Łódzkiego
}

\section{Wstęp}

Liczebność populacji więziennej ma ogromną wartość w nowoczesnym systemie penitencjarnym. Liczna populacja więzienna nie ma tych zalet, które można przypisywać grupie o optymalnej liczebności. Trudno ustalić, jakie rozmiary populacji więziennej można określić optymalnymi, racjonalnymi. W tej sytuacji łatwo o uproszczenia. Moje wieloletnie dociekania naukowe nad tą problematyką, uwzględniającą również wielkość populacji więziennej w krajach Europy Zachodniej, Środkowej i Wschodniej doprowadziły do wniosku, że optymalna liczebność populacji więziennej w Polsce to około 40 tys. uwięzionych, wówczas bowiem współczynnik prizonizacji wynosiłby około $100^{1}$. Wartości większe będą oznaczały populację więzienną dużych rozmiarów.

Wielkość populacji więziennej ma wpływ na funkcjonowanie systemu penitencjarnego, realizację instytucjonalnych celów wykonywania kary pozbawienia wolności i tymczasowego aresztowania. Populacje więzienne dużych rozmiarów stanowią wartość ujemną z wielu powodów. Wzrost po-

${ }^{1}$ A. Nawój-Śleszyński, Przeludnienie więzień w Polsce - przyczyny, następstwa i możliwości przeciwdziałania, Łódź 2013, s. 424. 
pulacji więziennej do rozmiarów dużych wcześniej czy później prowadzi do przeludnienia jednostek penitencjarnych wraz z jego negatywnymi skutkami. W przeludnionym więzieniu następuje patologiczne wypaczenie celów, które powinna realizować ta instytucja — kadra penitencjarna koncentruje się przede wszystkim na realizacji celów ochronnych kosztem zubożenia oddziaływań penitencjarnych. Wzrost populacji więziennej powoduje też wyczerpanie emocjonalne kadry. Ten stan jest zrozumiały, ponieważ wraz ze wzrostem liczby więźniów nie wzrasta proporcjonalnie liczba funkcjonariuszy i pracowników kadry penitencjarnej ${ }^{2}$. Przeludnione więzienie jest więzieniem niebezpiecznym. W związku z przeludnieniem w Polsce, które pojawiło się w 2000 roku, podejmowano różnorodne inicjatywy mające na celu przeciwdziałanie temu zjawisku, w tym poprzez redukcję populacji więziennej. Wyraźnym impulsem do kontroli tej kwestii był wyrok Trybunału Konstytucyjnego z dnia 26 maja 2008 roku (sygn. akt SK/07) ${ }^{3}$ oraz liczne interwencje organizacji strażniczych krajowych i zagranicznych. W 2010 roku przeludnienie więzienne w Polsce w znaczeniu jurydycznym zostało zlikwidowane. Współczynnik zaludnienia w tym roku osiągnął wartość 99,8\%; współczynnik prizonizacji zaś 218,0. Polska z takim wynikiem pozostawała w czołówce państw Europy. Ten stan rzeczy generował dla państwa duże koszty ekonomiczne, społeczne, których nie usprawiedliwiał poziom przestępczości stwierdzonej ${ }^{4}$. Następnym ważnym impulsem, który miał spowodować obniżenie wielkości populacji więziennej, była nowelizacja systemu prawa karnego ustawą z dnia 20 lutego $2015 \mathrm{roku}^{5}$, która weszła w życie w dniu 1 lipca 2017 roku. Projektodawca zaproponowanych zmian uznał, że istnieje potrzeba redukcji populacji więziennej, której rozmiary utrzymywały się na wysokim poziomie. $\mathrm{Z}$ uzasadnienia do projektu tej ustawy ${ }^{6}$ wynika, że przyczyny i uwarunkowania populacji więziennej dużych rozmiarów w Polsce zostały trafnie zdiagnozowane. Na

2 Ibidem, s. 147 n.

3 OTK-A 2008, nr 4, poz. 62, Dz.U. RP 2008/96/620, „Prokuratura i Prawo” 2008, nr 10, Lex nr 380071.

${ }^{4}$ T. Szymanowski, Nowelizacja kodeksu karnego w 2015 r., „Przegląd Więziennictwa Polskiego" 2015, nr 87, s. 7-8.

${ }^{5}$ Ustawa z dnia 20 lutego 2015 r. o zmianie ustawy — Kodeks karny oraz niektórych innych ustaw (Dz.U. poz. 390).

${ }^{6}$ Uzasadnienie do projektu ustawy o zmianie ustawy - Kodeks karny oraz niektórych innych ustaw z dnia 17 kwietnia 2014 r., druk sejmowy nr 2393, cz. 1, s. 1-2. 
liczebność osób uwięzionych miały wpływ następujące czynniki: wadliwa struktura orzekanych przez sądy kar kryminalnych, nadużywanie kary pozbawienia wolności i warunkowego zawieszenia jej wykonania oraz nieskuteczność systemu probacji, ponieważ niemal połowa osadzonych w zakładach karnych przebywa tam ze względu na zarządzenie wykonania kary pozbawienia wolności wcześniej zawieszonej przez sąd. Struktura kar kryminalnych orzekanych w Polsce daleko odbiega od krajów Europy Zachodniej - na przykład grzywna w Polsce stanowi 20\% wszystkich orzekanych kar, a w Wielkiej Brytanii 70\%, w Niemczech $80 \%$. Kara pozbawienia wolności z warunkowym zawieszeniem jej wykonania wynosi w Polsce 60\% wszystkich kar, tymczasem w Niemczech, Austrii, Wielkiej Brytanii, Holandii - poniżej 20\%. Intencją zmian w ustawodawstwie karnym była zmiana struktury orzekanych kar w ten sposób, aby przybliżyć ją do modelu niektórych państw Europy Zachodniej, tym samym zmniejszyć wielkość populacji więziennej w Polsce.

Celem niniejszego opracowania jest ustalenie, czy ta intencja zawarta w ustawie z dnia 20 lutego 2015 roku została zrealizowana, w jakim zakresie i stopniu, czy istnieją jakiekolwiek oznaki zmian w strukturze orzekanych kar oraz w jakim stopniu rozmiary populacji więziennej zostały pomniejszone. Należy zaznaczyć, że będzie to jedynie wstępna próba oceny zjawisk, które powinny nastąpić na skutek zmian wprowadzonych w kodeksie karnym, kodeksie karnym wykonawczym i innych dziedzinach prawa karnego. Ocena będzie odnosiła się do okresu dwóch lat — od 1 lipca 2015 roku do 30 czerwca 2017 roku. Nie jest to zbyt długi czas, aby zaobserwować wyraźne zmiany w strukturze orzekanych kar kryminalnych i pomniejszenie populacji więziennej. Mam jednak nadzieję, że ocena funkcjonowania znowelizowanego prawa karnego w tym okresie pozwoli stwierdzić, czy pojawily się oczekiwane tendencje w polityce karnej sądów. Głębszej, systemowej analizy i oceny realizacji celów znowelizowanego prawa będzie można dokonać po upływie dłuższego okresu. Na ostateczną ocenę trzeba oczekiwać z nadzieją, że ratio legis kary pozbawienia wolności, zawarte w znowelizowanym kodeksie karnym z 20 lutego 2015 roku, nie legnie w gruzach, jak to się stało w czasie funkcjonowania kodeksu karnego przed omawianą nowelizacją. Rozwiązania prawne zawarte w kodeksie karnym z 1997 roku mogły dobrze służyć kształtowaniu ra- 
cjonalnej struktury stosowanych kar kryminalnych i optymalnej wielkości populacji więziennej. Nie zawiodły przepisy, lecz ci, którzy je stosowali.

\section{Struktura kar kryminalnych orzekanych przez sądy} pierwszej instancji w Polsce w latach 2014, 2015 i 2016

Celem zmian w polityce karnej na podstawie prawa karnego znowelizowanego ustawą z dnia 20 lutego 2015 roku była redukcja populacji więziennej poprzez zmianę struktury orzekanych kar. Zmiany w polityce karnej na podstawie znowelizowanego prawa można obserwować dopiero od połowy 2015 roku, całego 2016 i do połowy 2017. Co do ostatniego roku ta obserwacja jest obecnie nierealna ze względu na brak danych statystycznych. Próbę oceny zmian w orzecznictwie sądów w 2015 roku podjęła już M. Melezini ${ }^{7}$. Oczekiwania w zakresie ocen efektów polityki karnej istnieją, są ważne. Czy jednak te efekty są zgodne z założeniami znowelizowanego prawa karnego? Analiza kar orzeczonych przez sądy pierwszej instancji (sądy rejonowe i okręgowe) wskazuje, że ich struktura w niedługim czasie uległa zauważalnym zmianom. Tabela 1 obrazuje częstotliwość kar izolacyjnych i nieizolacyjnych orzekanych w latach 2014, 2015 i 2016. Dane statystyczne za rok 2014 są punktem odniesienia do zmian, które następowały w kolejnych latach na skutek znowelizowanego prawa karnego. Na podstawie danych zestawionych w tabeli 1 można zauważyć, że rysuje się tendencja spadkowa orzekania przez sądy kar izolacyjnych na rzecz wzrostu orzekanych kar nieizolacyjnych. Ta tendencja występuje bardzo wyraźnie w orzeczeniach sądów rejonowych. Skazania przez sądy okręgowe jako sądy pierwszej instancji w niewielkim stopniu zmieniają obraz orzecznictwa, ponieważ udział tych orzeczeń w ogólnej liczbie skazań jest niewielki: w 2015 roku wynosił 3\%, w 2016 roku 2,9\% ogółu skazań. Szczególną uwagę zwracają tendencje orzekania kar zarówno przez sądy rejonowe, jak i okręgowe jako sądów pierwszej instancji.

${ }^{7}$ M. Melezini, Polityka karna sądów w kontekście reformy prawa karnego. Wstępne wyniki badań, „Nowa Kodyfikacja Prawa Karnego” 43, 2017, s. 421-440. 


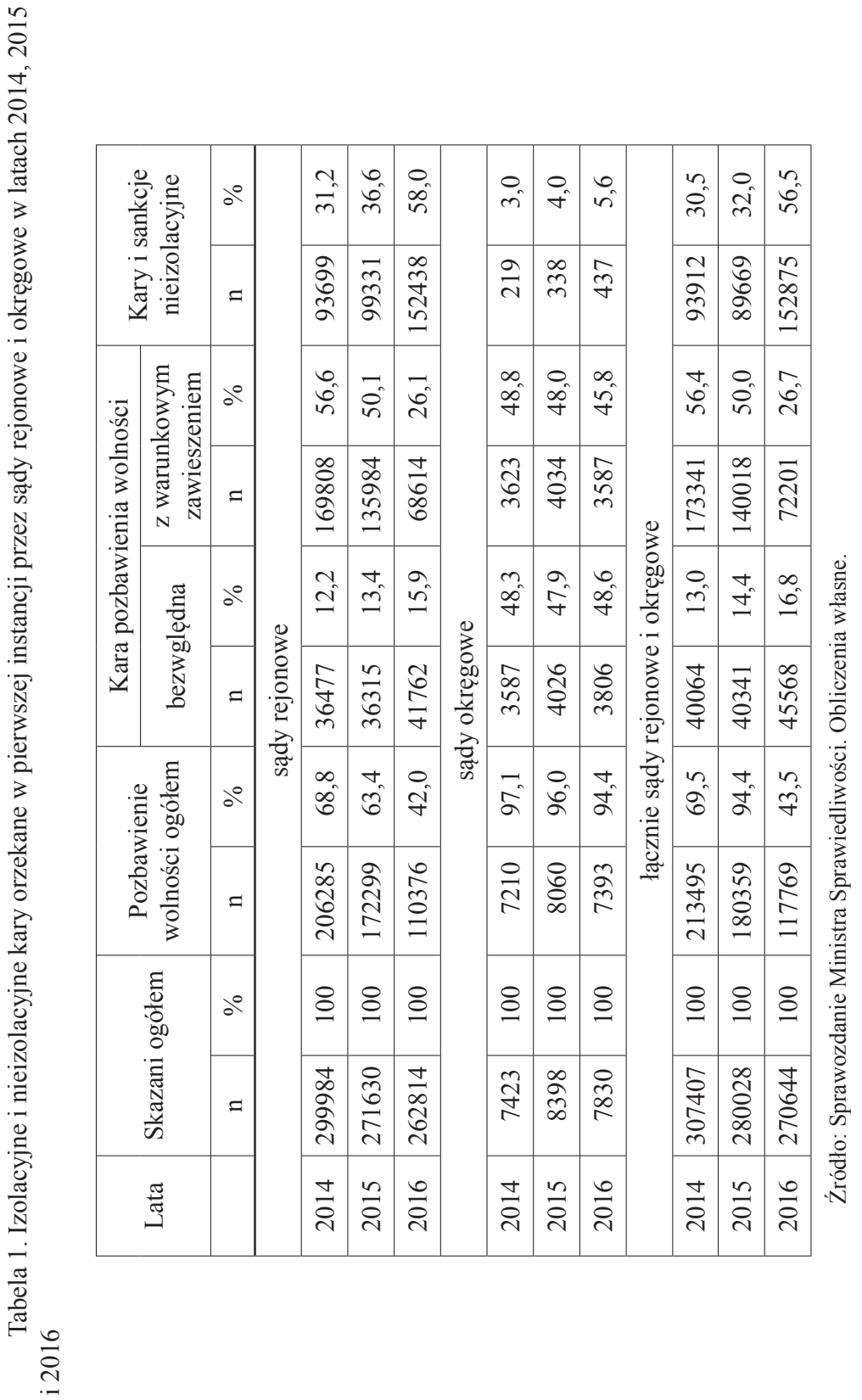


W badanym okresie następuje:

- spadek skazań na karę pozbawienia wolności ogółem z 69,4\% w 2014 roku do 43,5\% w 2016 roku — spadek wynosi 25,9\%;

- spadek orzeczeń kary pozbawienia wolności z warunkowym zawieszeniem jej wykonania z 56,6\% w 2014 roku do 26,7\% w 2016 roku - spadek o 29,3\%;

- wzrost liczby orzeczeń na bezwzględną karę pozbawienia wolności z 13\% w 2014 roku do 16,8\% w 2016 roku, tj. o 2,8\%;

- wzrost orzekanych kar nieizolacyjnych z 30,6\% w 2014 roku do $56,4 \%$ w 2016 roku — wzrost o 25,8\%.

Z zaprezentowanego zestawienia wyłania się wyraźnie oczekiwany model prawno-karnej reakcji na przestępstwo — już po półtora roku stosowania znowelizowanego prawa karnego w strukturze orzekanych kar przeważają kary nieizolacyjne. Czy należy się niepokoić wzrostem orzekanych kar pozbawienia wolności bez warunkowego zawieszenia ich wykonania? Wydaje się, że nie. Po pierwsze, jest to być może przejściowa reakcja na ograniczenie możliwości orzekania kary pozbawienia wolności z warunkowym zawieszeniem do 1 roku i sięganie w najprostszy sposób po tę karę, zamiast poszukiwać i stosować nieizolacyjne alternatywy, które przewiduje kodeks karny. Po drugie, wzrost liczby orzekanych kar pozbawienia wolności nie musi prowadzić do zwiększenia populacji więziennej. W Polsce duży udział w rozmiarach populacji więziennej miał niesprawny system probacyjny, którego skutkiem było to, że około 50\% populacji więziennej stanowiły osoby, którym odwieszono karę pozbawienia wolności, warunkowo zawieszoną. Z danych statystycznych, które już cytowano, wynika, że w strukturze orzekanych kar nastąpił duży spadek liczby orzekanych kar pozbawienia wolności z warunkowym zawieszeniem ich wykonania, co będzie skutkowało mniejszym napływem do więzienia osób, którym została odwieszona kara pozbawienia wolności. Ten fakt może mieć wpływ na zmniejszenie populacji więziennej. Nie można jednak lekceważyć pojawiających się tendencji wzrostu orzekanych przez sądy kar pozbawienia wolności bez warunkowego zawieszenia ich wykonania.

Model struktury kar orzekanych przez sądy okręgowe jako sądy pierwszej instancji odbiega od ogólnego modelu, który już został omówiony, oraz modelu kar orzekanych przez sądy rejonowe jako sądów pierwszej instancji. Struktura kar orzekanych przez sądy okręgowe, w której dominuje kara pozbawienia wolności (bezwzględna i z wa-

Nowa Kodyfikacja Prawa Karnego 48, 2018 (C) for this edition by CNS 
runkowym zawieszeniem), jest zrozumiała ze względu na większy stopień niebezpieczeństwa czynów zabronionych prawem, które osądza sąd okręgowy. Rozmiary tych orzeczeń sądów nie wpływają w stopniu znaczącym na wielkość populacji więziennej. Oddziałują na to przede wszystkim orzeczenia sądów rejonowych, ponieważ skazania przez te sądy stanowią 97\% wszystkich skazań w latach 2015-2016.

W związku z tym zostanie przybliżona struktura kar orzekanych w pierwszej instancji przez rejonowe. W badanych latach występowały następujące tendencje w orzekaniu kar przez sądy rejonowe jako sądy pierwszej instancji:

— spadek orzekanych kar izolacyjnych z 68,8\% w 2014 roku do 42\% w 2016 roku — spadek o 26,8\%;

- gwałtowny spadek orzekanych kar pozbawienia wolności z warunkowym zawieszeniem ich wykonania z 56,6\% w 2014 roku do 26,1\% w 2016 roku — spadek o 30,5\%;

- wzrost orzekanych kar pozbawienia wolności bez warunkowego zawieszenia ich wykonania z 12,2\% w 2014 roku do 15,9\% w 2016 roku - wzrost o $3,7 \%$;

— wzrost orzekanych kar ograniczenia wolności z 11,4\% w 2014 roku do 23,1\% w 2016 roku, tj. o 11,7\%;

— wzrost orzekanych grzywien samoistnych z 19,8\% w 2014 roku do $33,5 \%$ w 2016 roku, tj. o 13,7\%;

- w strukturze orzekanych kar pojawia się kara mieszana, która w 2015 roku stanowiła 729 przypadków, a w 2016 roku już 3542 przypadków.

Podsumowując, należy stwierdzić, że w okresie półtora roku obowiązywania prawa karnego znowelizowanego ustawą z dnia 20 lutego 2015 roku nastąpiła zmiana w strukturze kar orzekanych przez sądy. Jest ona wyraźna w 2016 roku i zaczęła się zbliżać do struktury oczekiwanej przez ustawodawcę nowelizacji. To właśnie w 2016 roku w strukturze orzeczonych kar zaczyna przeważać kara grzywny samoistnej (33,5\%). Częstotliwość orzekania tej kary odbiega jeszcze od oczekiwań, za to odsetek orzeczonej kary ograniczenia wolności nieco przekracza oczekiwania. Problemem pozostaje redukcja kar izolacyjnych do poziomu $20 \%$, a zatem mniejsze o połowę orzekanie ich przez sądy rejonowe. Wydaje się, że taka możliwość istnieje, zmieniając w dalszym ciągu politykę karną w zakresie orzekania kar krótko- i średnioterminowych, dla których naturalną alternatywą są kary nieizolacyjne.

Nowa Kodyfikacja Prawa Karnego 48, 2018

(C) for this edition by CNS 


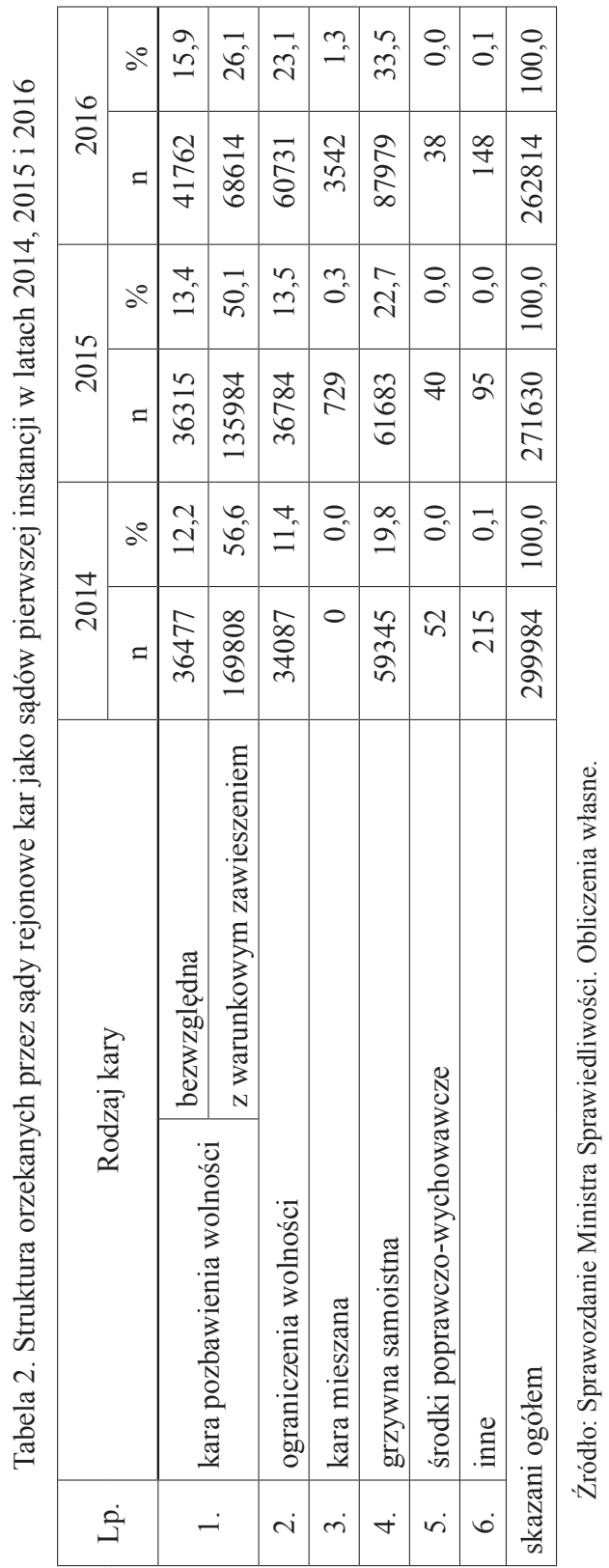

Nowa Kodyfikacja Prawa Karnego 48, 2018 (C) for this edition by CNS 


\section{Skazani na karę pozbawienia wolności w populacji więziennej w okresie od 1 lipca 2015 do 30 czerwca 2017 roku}

$\mathrm{Na}$ podstawie danych statystycznych, które były przedmiotem analizy w poprzednim rozdziale, należałoby oczekiwać, że zmiany w strukturze orzekanych kar kryminalnych będą miały wpływ na pomniejszenie populacji skazanych na karę pozbawienia wolności. Za takimi oczekiwaniami przemawiał wzrost orzekanych kar nieizolacyjnych (kary ograniczenia wolności, grzywny samoistnej) oraz spadek orzekanych kar pozbawienia wolności z warunkowym zawieszeniem jej wykonania. Wielkości populacji więziennej nie można oceniać tylko na podstawie liczebności osób, które przebywają w więzieniu, mając orzeczoną przez sąd karę pozbawienia wolności. Populacja więzienna nie jest bytem jednorodnym. Jednym z podstawowych kryteriów, które różnicują ją na podgrupy, są podstawy prawne uwięzienia. W skład populacji więziennej zatem wchodzą skazani na zasadniczą lub zastępczą karę pozbawienia wolności, tymczasowo aresztowani i ukarani ${ }^{8}$. Przy ocenie punitywności systemu wymiaru sprawiedliwości karnej bierze się pod uwagę sumę wszystkich tych trzech grup osób pozbawionych wolności. Miarą punitywności systemu wymiaru sprawiedliwości karnej jest współczynnik prizonizacji, który wyraża się liczbą osób uwięzionych przypadających na 100 tys. mieszkańców w określonym czasie. Tak więc na wielkość populacji więziennej wpływ ma liczebność wymienionych grup oraz tendencje rozwojowe ich wielkości w czasie. Zmniejszenie populacji więziennej można osiągnąć poprzez redukcję poszczególnych grup. Największą grupą osób uwięzionych są skazani na bezwzględną karę pozbawienia wolności. Zamysłem projektodawcy prawa karnego znowelizowanego ustawą z dnia 20 lutego 2015 roku, obowiązującą od 1 lipca 2015 roku, było między innymi urzeczywistnienie w polityce karnej zasady prymatu kar wolnościowych (ultima ratio), co w konsekwencji miało ograniczyć orzekanie krótko- i średnioterminowych kar pozbawienia wolności, a w konsekwencji wpłynąć na redukcję populacji więziennej. Czy ten cel

8 Ukarany jest osobą odbywającą karę orzeczoną za wykroczenie albo karę porządkową, a także osobą, wobec której jest stosowany środek przymusu skutkujący pozbawieniem wolności - por. $\S 52$ pkt 2 i $\S 53$ pkt 3 rozporządzenia Ministra Sprawiedliwości z dnia 25 sierpnia 2003 r. w sprawie regulaminu organizacyjno-porządkowego wykonywania kary pozbawienia wolności (Dz.U. Nr 152, poz. 1493). 
został osiągnięty? Odpowiedź na tak postawione pytanie jest jeszcze przedwczesna. Można i należy oceniać wstępne wyniki z dwóch lat stosowania znowelizowanego prawa, tj. od 1 lipca 2015 do 30 czerwca 2017 roku. Okres ten podzielono na osiem kwartałów (dwa w 2015 roku, cztery w 2016, dwa w 2017). Skonstruowany szereg chronologiczny na podstawie kwartałów pozwolił na określenie udziału zbiorowości skazanych na karę pozbawienia wolności w populacji więziennej oraz zaobserwowanie tendencji rozwojowych tego zjawiska. Oceniając wskaźnik dynamiki za osiem kwartałów, przyjęto drugi kwartał 2015 roku za 100. Do końca drugiego kwartału tego roku nie działało znowelizowane prawo karne - zaczęło ono obowiązywać od trzeciego kwartału 2015 roku. Powinno ono skutkować oczekiwanymi zmianami w polityce karnej, przede wszystkim redukcją liczby osób skazanych na karę pozbawienia wolności w populacji ogólnowięziennej.

W badanym okresie populacja więzienna ulegała procesowi powolnej redukcji, począwszy od trzeciego kwartału 2015 roku do czwartego kwartału 2016 roku, czyli w okresie dwóch lat. Pomniejszenie populacji więziennej w tym czasie wynosiło 1833 osoby. Na szczególną uwagę zasługuje ocena dynamiki i tendencje rozwojowe populacji skazanych na karę pozbawienia wolności w zbiorowości więziennej, ponieważ reforma prawa karnego w szczególności dotyczy tych osób. Skazani stanowią największą grupę w populacji więziennej, bo około 90\% wszystkich uwięzionych. Udział tej grupy w całej populacji ulegał stopniowemu pomniejszeniu. Wskaźniki dynamiki wyraźnie pokazują, że ten proces przebiegał w dwóch fazach. Pierwsza to okres od trzeciego kwartału 2015 roku do czwartego kwartału 2016 roku; druga faza to pierwsze półrocze 2017 roku, w którym w pierwszym kwartale nastąpił wzrost liczby skazanych w populacji więziennej. Czy w następnym kwartale nastąpił spadek? Zmniejszenie liczby skazanych w populacji więziennej w badanym okresie mierzone odsetkami nie jest imponujące Nie można jednak nie zauważyć, że liczba skazanych w populacji więziennej w ciągu dwóch lat została pomniejszona o 2746 osób. W badanym okresie nastąpiło zjawisko wyraźnej tendencji wzrostowej w populacji więziennej liczby osób tymczasowo aresztowanych. Dlaczego tak się stało? Odpowiedź na tak postawione pytanie znajduje się poza zasięgiem moich dociekań. W podsumowaniu tej części rozważań należy stwierdzić, że cele reformy prawa karnego znowelizowanego ustawą z dnia 20 lutego 2015 roku zostały osiągnięte. Liczba skazanych na karę pozbawienia wolności w populacji więziennej zmniejszyła się o 4\%. 


\begin{tabular}{|c|c|c|c|c|c|c|c|c|c|c|}
\hline \multirow{3}{*}{$\begin{array}{l}\frac{1}{0} \\
\frac{0}{0} \\
0 \\
0\end{array}$} & 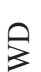 & $\begin{array}{l}0 \\
8 \\
8\end{array}$ & $\begin{array}{l}\hat{a} \\
\hat{n}\end{array}$ & $\hat{n}$ & \begin{tabular}{l}
$\infty$ \\
\multirow{\sigma}{*}{}
\end{tabular} & & 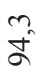 & $\stackrel{n}{8}$ & $\stackrel{\sim}{\infty}$ & $\begin{array}{l}0 \\
\hat{a}\end{array}$ \\
\hline & $\frac{\pi}{3}$ & $\begin{array}{l}0 \\
8 \\
8\end{array}$ & $\begin{array}{l}0 \\
8 \\
8\end{array}$ & $\begin{array}{l}0 \\
8 \\
8\end{array}$ & $\stackrel{0}{8}$ & $\stackrel{\circ}{8}$ & $\stackrel{0}{8}$ & $\stackrel{\circ}{8}$ & $\stackrel{0}{8}$ & $\stackrel{0}{8}$ \\
\hline & Z & $\begin{array}{l}\bar{\sigma} \\
\stackrel{n}{n}\end{array}$ & $\begin{array}{l}\text { Oे } \\
\text { 요 }\end{array}$ & $\begin{array}{l}o \\
\stackrel{2}{2} \\
\stackrel{2}{2}\end{array}$ & $\begin{array}{l}\infty \\
\infty \\
\approx\end{array}$ & $\stackrel{\text { ஒே }}{\stackrel{2}{\circ}}$ & $\frac{i n}{n}$ & $\stackrel{\substack{N \\
N}}{\underset{n}{n}}$ & $\frac{m}{\stackrel{n}{I}}$ & $\begin{array}{l}\infty \\
\infty \\
\infty \\
m\end{array}$ \\
\hline \multirow{3}{*}{ 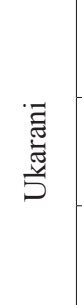 } & 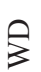 & $\stackrel{0}{8}$ & $\stackrel{+}{\text { ন }}$ & $\hat{\sigma}$ & $\begin{array}{l}0 \\
\infty \\
\infty\end{array}$ & $\hat{\infty}$ & $\tilde{n}$ & ळे & $\bar{a}$ & ?̊ \\
\hline & 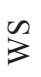 & $\stackrel{0}{\sim}$ & $\stackrel{n}{=}$ & $\stackrel{0}{-}$ & $\stackrel{0}{=}$ & $\stackrel{0}{=}$ & $\stackrel{0}{=}$ & $\stackrel{n}{=}$ & $\stackrel{0}{=}$ & 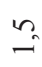 \\
\hline & $=$ & $\stackrel{n}{\infty}$ & $\stackrel{2}{\circ}$ & $\stackrel{\varrho}{\equiv}$ & $\vec{\sigma}$ & $\stackrel{ }{\beth}$ & $\stackrel{\cong}{\Xi}$ & $\stackrel{\Re}{2}$ & $\stackrel{ \pm}{\Xi}$ & $\stackrel{0}{0}$ \\
\hline \multirow{3}{*}{ 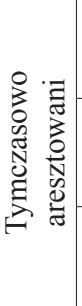 } & $\$$ & $\stackrel{0}{8}$ & 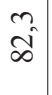 & $\stackrel{n}{\infty}$ & กे & 2 & $\tilde{8}$ & $\stackrel{\infty}{0}$ & $\stackrel{\cong}{\cong}$ & $\stackrel{n}{2}$ \\
\hline & 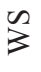 & $\stackrel{\circ}{\circ}$ & $\hat{\sigma}^{\circ}$ & nे & $\overrightarrow{6}$ & $\hat{\sigma}$ & $n$ & $n$ & $\stackrel{\infty}{\infty}$ & $\infty_{\infty}^{\circ}$ \\
\hline & $=$ & $\begin{array}{l}8 \\
\stackrel{n}{n} \\
\text { nn }\end{array}$ & 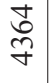 & $\frac{\widetilde{V}}{\forall}$ & $\stackrel{\curvearrowright}{\curvearrowright}$ & 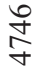 & $\underset{\text { กิ }}{\stackrel{ \pm}{n}}$ & $\begin{array}{l}\circ \\
\text { ๙ે} \\
\text { nิ }\end{array}$ & $\overrightarrow{\hat{n}}$ & $\overrightarrow{\text { అె }}$ \\
\hline \multirow{3}{*}{ 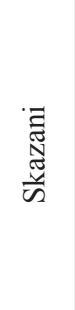 } & 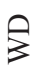 & $\stackrel{0}{8}$ & $\begin{array}{l}\hat{a} \\
\text { an }\end{array}$ & $\begin{array}{l}\sigma^{\prime} \\
\dot{a}\end{array}$ & $\stackrel{n}{n}$ & $\begin{array}{l}0 \\
\text { å }\end{array}$ & $\underset{\sigma}{\infty}$ & $\begin{array}{l}0 \\
\text { İ }\end{array}$ & $\vec{a}$ & \begin{tabular}{l}
$\circ$ \\
\multirow{2}{0}{}
\end{tabular} \\
\hline & $\frac{\pi}{3}$ & $\frac{\nabla_{0}}{a}$ & สิ & 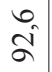 & $\tilde{\Omega}$ & $\hat{a}$ & $\frac{0}{a}$ & $\frac{0}{a}$ & $\stackrel{+}{\circ}$ & ᄋ. \\
\hline & $=$ & $\begin{array}{l}\stackrel{8}{\delta} \\
\text { న్ర }\end{array}$ & $\frac{i}{\pi}$ & 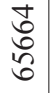 & $\begin{array}{l}\text { లి } \\
\text { రై }\end{array}$ & 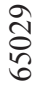 & $\begin{array}{l}\overrightarrow{8} \\
\text { す্ }\end{array}$ & 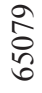 & $\frac{\infty}{\infty}$ & \begin{tabular}{l}
$\stackrel{+}{n}$ \\
\multirow{2}{*}{}
\end{tabular} \\
\hline \multirow{2}{*}{\multicolumn{2}{|c|}{ 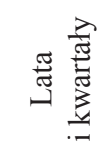 }} & $\exists$ & $\Xi$ & $\geq$ & - & 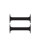 & $\Xi$ & $\geq$ & • & 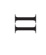 \\
\hline & & & $\frac{n}{0}$ & & & & & & & \\
\hline
\end{tabular}




\section{Skazani na zastępczą karę pozbawienia wolności w populacji więziennej w okresie od 1 lipca 2015 do 30 czerwca 2017 roku}

Ustawodawca znowelizowanego prawa karnego z 20 lutego 2015 roku zakładał ograniczenie wykonywania zastępczych kar pozbawienia wolności, co znalazło wyraz w dodanych wspomnianą ustawą do kodeksu karnego wykonawczego art. 48a i 65a. Czy przez dwa lata zostały osiągnięte zamierzone efekty? Próba odpowiedzi na to pytanie będzie podjęta w dalszej części opracowania. Skazani na zastępczą karę pozbawienia wolności stanowią niewielki odsetek osób uwięzionych. Rozmiary tego zjawiska obrazuje tabela $4 . \mathrm{Z}$ danych $\mathrm{w}$ niej przedstawionych wynika, że w ciągu badanych dwóch lat rozmiary tej grupy osób pozbawionych wolności osiągają od 3,5\% do 5,3\% populacji ogólnowięziennej. Rozmiary tej grupy osób zatem w niewielkim stopniu mogą wpływać na wielkość populacji ogólnowięziennej. Poszukiwanie wszelkich możliwości redukcji wielkości populacji więziennej jest racjonalne, bo ich suma może dać efekt redukcji populacji ogólnowięziennej do racjonalnych rozmiarów. Na podstawie art. 48a k.k.w. sąd może w każdym czasie wstrzymać wykonywanie zastępczej kary pozbawienia wolności w wypadkach, o których mowa w art. $48 \S 1$ pkt 1 k.k.w., jeżeli skazany oświadczy na piśmie, że podejmie pracę społecznie użyteczną i podda się rygorom z nią związanym. Na podstawie art. $65 \mathrm{a} \S 1$ pkt 1 k.k.w. sąd w każdym czasie może wstrzymać wykonanie zastępczej kary pozbawienia wolności, w wypadku gdy skazany oświadczy na piśmie, że podejmie odbywanie kary ograniczenia wolności i podda się rygorom z tym związanym. Te rozwiązania prawne mają wiele walorów, w tym ograniczenie rozmiarów populacji więziennej. Czy cel nowelizacji kodeksu karnego wykonawczego, polegający na zmniejszeniu liczebności osób, wobec których jest wykonywana zastępcza kara pozbawienia wolności, został osiągnięty? Oceny zamierzonych efektów nie można uznać za pozytywną. $Z$ danych w tabeli 4 wynika, że w badanych latach następuje spadek liczby skazanych na zasadniczą karę pozbawienia wolności i wzrost liczby skazanych na zastępczą karę pozbawienia wolności. Udział procentowy odbywających zastępczą karę pozbawienia wolności w okresie dwóch lat przejawia tendencję wzrostową — jest ona bardzo wyraźna 
w pierwszym półroczu 2017 roku i wynosi ponad 40\% w stosunku do okresu wyjściowego. Oczekiwania ustawodawcy wobec ograniczenia wykonywania zastępczej kary pozbawienia wolności się nie spełniły. Coraz częstsze orzekanie zastępczej kary pozbawienia wolności zwiększa stan zaludnienia zakładów karnych skazanymi na krótkoterminowe kary pozbawienia wolności ${ }^{9}$. Przyczyn takiego stanu rzeczy z pewnością jest wiele. W tym miejscu trudno o nich przesądzać, należałoby jednak poświęcić im odrębne badania empiryczne. Można już teraz zaryzykować tezę, że jedną z nich jest duży wzrost orzekanych nieizolacyjnych kar kryminalnych w okresie od 1 lipca 2015 do 30 czerwca 2017 roku, w szczególności kary grzywny samoistnej.

Tabela 4. Struktura i dynamika populacji skazanych na karę pozbawienia wolności w okresie od 1 lipca 2015 do 30 czerwca 2017 roku

\begin{tabular}{|c|c|c|c|c|c|c|c|}
\hline \multirow{2}{*}{\multicolumn{2}{|c|}{$\begin{array}{c}\text { Lata } \\
\text { i kwartały }\end{array}$}} & \multicolumn{6}{|c|}{ Skazani na karę pozbawienia wolności } \\
\hline & & \multicolumn{3}{|c|}{$\begin{array}{c}\text { Kara zasadnicza } \\
\text { pozbawienia wolności }\end{array}$} & \multicolumn{3}{|c|}{$\begin{array}{c}\text { Kara zastępcza } \\
\text { pozbawienia wolności }\end{array}$} \\
\hline & & $\mathrm{n}$ & WS & WD & $\mathrm{n}$ & WS & WD \\
\hline \multirow{3}{*}{2015} & II & 66482 & 94,4 & 100,0 & 2724 & 3,9 & 100,0 \\
\hline & III & 64620 & 94,7 & 97,2 & 2530 & 3,7 & 92,9 \\
\hline & IV & 63654 & 94,3 & 95,7 & 2702 & 4,0 & 99,2 \\
\hline \multirow{4}{*}{2016} & I & 63272 & 93,9 & 95,2 & 2958 & 4,4 & 108,6 \\
\hline & II & 62236 & 94,0 & 93,6 & 2793 & 4,2 & 102,5 \\
\hline & III & 62032 & 93,9 & 93,3 & 2869 & 4,3 & 105,3 \\
\hline & IV & 61180 & 93,4 & 92,0 & 3259 & 5,0 & 119,6 \\
\hline \multirow{2}{*}{2017} & I & 63209 & 92,5 & 95,1 & 3959 & 5,8 & 145,3 \\
\hline & II & 62625 & 92,7 & 94,2 & 3829 & 5,7 & 140,6 \\
\hline
\end{tabular}

Źródło: Kwartalna Informacja Statystyczna CZSW. Obliczenia własne.

9 S. Lelental, M. Niewiadomska-Krawczyk, Orzekanie i wykonywanie zastępczych kar pozbawienia wolności, [w:] Czy i jakie więzienia sq potrzebne, red. P. Stępniak, T. Kalisz, W. Zalewski, Poznań 2016, s. 200.

Nowa Kodyfikacja Prawa Karnego 48, 2018 (C) for this edition by CNS 


\section{Skazani na kary krótko- i średnioterminowe pozbawienia wolności w populacji więziennej w okresie od 1 lipca 2015 do 30 czerwca 2017 roku}

Jedną z przyczyn dużych rozmiarów populacji więziennej w Polsce była wadliwa polityka karna polegająca na zbyt częstym orzekaniu przez sądy krótkoterminowych kar pozbawienia wolności. Takiej praktyce miała zapobiegać zasada priorytetu orzekania kar wolnościowych (ultima ratio), która w znowelizowanym art. 58 k.k. daje jeszcze większe możliwości sięgania przez sąd po sankcje karne niezwiązane z pozbawieniem wolności. Powstaje pytanie, $\mathrm{w}$ jakim stopniu zmieniła się struktura wykonywanych kar pozbawienia wolności w wymiarze do 5 lat, z chwilą wejścia w życie prawa karnego znowelizowanego ustawą z dnia 20 lutego 2015 roku. Należałoby oczekiwać, że w strukturze wykonywanych kar krótkoterminowych i średnioterminowych rysuje się tendencja spadkowa. Ta hipoteza zostanie zweryfikowana na podstawie statystyk penitencjarnych, które zobrazują tendencję rozwojową populacji więziennej w okresie do 5 lat. Przedmiotem oceny będzie obserwacja wymienionego zjawiska w ciągu dwóch lat, tj. dwóch kwartałów 2015 roku, czterech kwartałów 2016 roku i dwóch kwartałów 2017 roku. Z danych statystycznych wynika, że w dwóch ostatnich latach zarysowała się niewielka tendencja spadkowa liczby skazanych odbywających karę do 5 lat, z 85,3\% w drugim kwartale 2015 roku do 83,6\% w drugim kwartale 2017 roku. Jest to spadek o $1,7 \%$. Należy jednak podkreślić, że udział skazanych na kary krótkoterminowe i średnioterminowe w populacji więziennej jest bardzo duży, bo wynosi ponad $80 \%$ ogólnej populacji więziennej. 


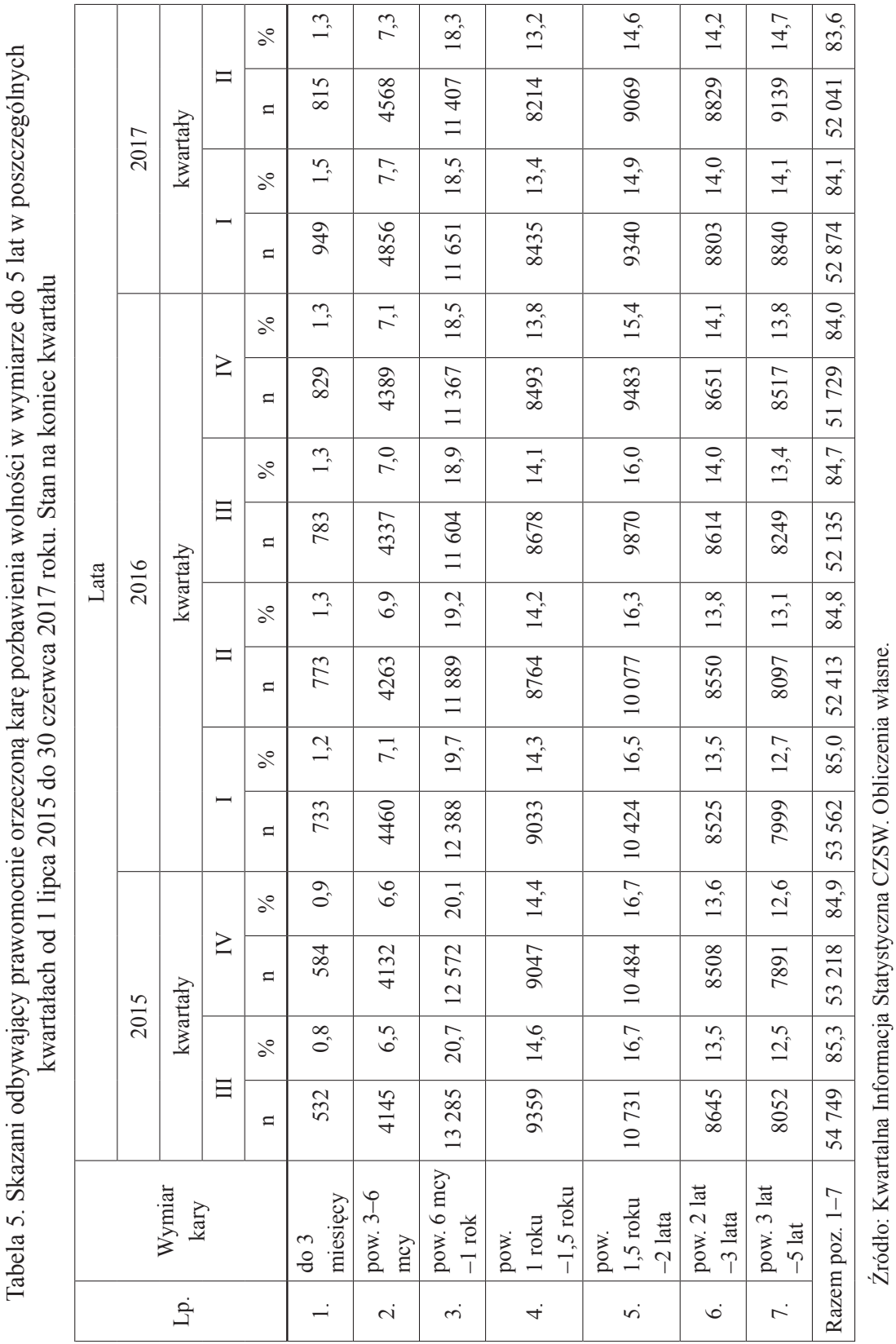


Z tabeli 6 wynika, że dynamika populacji więziennej osób odbywających karę pozbawienia wolności do 5 lat w zależności od wymiaru kary jest zróżnicowana i nie zawsze ma tendencję spadkową. Charakterystyczną cechą jest, że w badanym okresie następuje wzrost w populacji więziennej grupy skazanych na kary do 3 miesięcy i od 3 miesięcy do 6 miesięcy oraz powyżej 3 do 5 lat. Wskaźnik dynamiki w pierwszym wypadku był największy, bo na koniec badanego okresu wynosił 138,8 , w drugim wypadku 102,1, a ostatnim 111,2. W pozostałych grupach więźniów, których wymiar kary nie przekraczał 5 lat, następował spadek - największy w przedziale 1,6-2 lata wymiaru kary, wskaźnik dynamiki wyniósł 82,4. Ogółem grupa skazanych, których wymiar kary przekroczył 5 lat, w ogólnej strukturze osób uwięzionych miała tendencję spadkową. Tempo spadku mierzone wskaźnikiem dynamiki nie było zbyt duże: na początku badanego okresu wskaźnik dynamiki wynosił 96,6, na koniec — 92,1. Różnica wyniosła 4,8. Trzeba jeszcze trochę czasu, by upewnić się, czy zaobserwowana tendencja spadkowa ma charakter ciągły i wyraźnie zmniejszający udział tej grupy skazanych w populacji więziennej, co powinno nastąpić, jeśli wziąć pod uwagę zmianę polityki karnej. Zmiany realizacji polityki karnej, które już nastąpiły, nie mają jeszcze przełożenia na wyraźne zmniejszenie populacji więziennej, w szczególności w grupie skazanych na kary krótkoterminowe i średnioterminowe, w których to obszarach istnieją największe rezerwy redukcji populacji więziennej. 


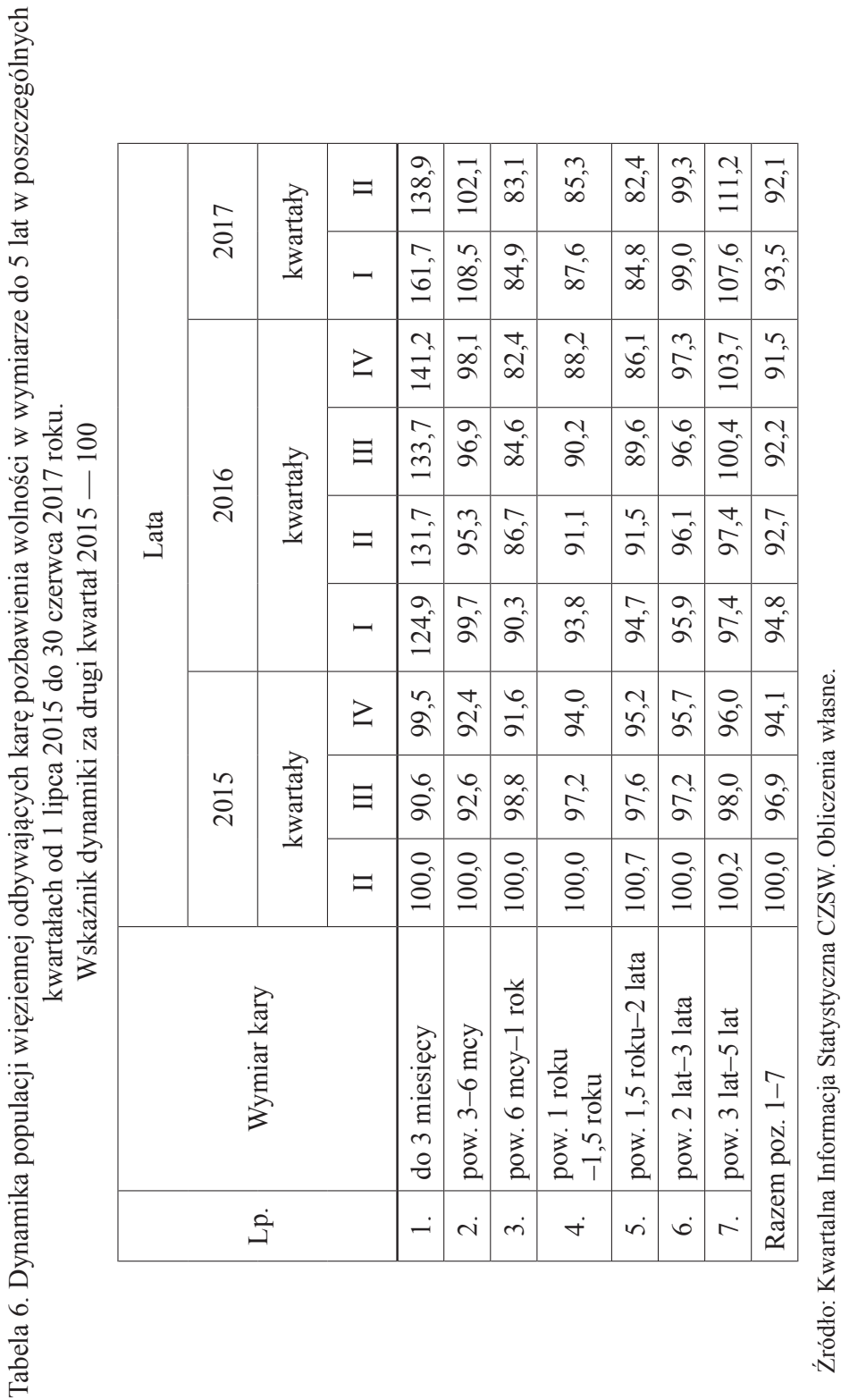




\section{Rola dozoru elektronicznego w zmniejszaniu populacji więziennej}

Dozór elektroniczny pojawił się w polskim porządku prawnym jako narzędzie redukcji populacji więziennej w okresie wzrostu liczebności osób pozbawionych wolności, który skutkował przeludnieniem więziennym w latach 2000-2010. Aktualnie istnieje bogata literatura naukowa ${ }^{10}$ wyjaśniająca genezę, charakter i skutki wprowadzenia do polskiego systemu prawnego nowej formy wykonywania krótkoterminowej kary pozbawienia wolności poza zakładem karnym w systemie dozoru elektronicznego na podstawie ustawy z dnia 7 września 2007 roku o wykonywaniu kary pozbawienia wolności poza zakładem karnym w systemie dozoru elektronicznego $^{11}$, która weszła w życie w dniu 1 września 2009 roku. Z tą datą stało się możliwe wykonywanie kary pozbawienia wolności w systemie dozoru elektronicznego. Wdrażanie owego systemu odbywało się etapami, a stosowanie go zostało zmienione w dniu 30 czerwca 2015 roku ustawą z dnia 20 lutego 2015 roku o zmianie ustawy - Kodeks karny oraz niektórych innych ustaw ${ }^{12}$. Na podstawie tej ustawy z dniem 1 lipca 2015 roku dozór elektroniczny przestał być systemem wykonywania kary pozbawienia wolności, stając się elementem, który zwiększał dolegliwość kary ograniczenia wolności ${ }^{13}$. Po 1 lipca 2015 roku następuje diametralny spadek liczby osób objętych tych systemem. W tym roku orzeczono karę ograniczenia wolności z systemem dozoru elektronicznego w 126 przypadkach, co stanowi $0,3 \%$ orzeczonych kar ograniczenia wolności ${ }^{14}$. Ten fakt stał się argumentem przywrócenia stosowania systemu dozoru elektronicznego jako formy wykonywania kary pozbawienia wolności ustawą z dnia 11 marca 2016 roku o zmianie ustawy Kodeks karny — kodeks karny wykonawczy ${ }^{15}$, która weszła w życie 15 kwietnia 2016 roku. W związ$\mathrm{ku} \mathrm{z}$ dotychczasowymi rozważaniami rodzą się następujące pytania, czy

10 S. Lelental, Kodeks karny wykonawczy. Komentarz, Warszawa 2017, s. 179-181.

11 Dz.U. z 2017 r., Nr 191, poz. 1366.

12 Dz.U. z 2015 r., poz. 396.

13 K. Dąbkiewicz, Kodeks karny wykonawczy. Komentarz do nowelizacji 2016 r., Warszawa 2016 r., s. 5.

14 M. Melezini, op. cit., s. 426.

15 Dz.U. z 2016 r., poz. 428. 
i w jakim stopniu wprowadzenie do polskiego prawa karnego wykonawczego możliwości wykonywania kary pozbawienia wolności poza zakładem karnym w systemie dozoru elektronicznego miało wpływ na redukcję populacji więziennej. Drugie pytanie można zadać na temat zmiany wykorzystania dozoru elektronicznego ustawą z dnia 20 lutego 2015 roku (kara ograniczenia wolności, niektóre środki karne, środki zabezpieczające) czy mogła mieć wpływ na redukcję populacji więziennej? W pierwszym wypadku skutki wykonywania kary pozbawienia wolności poza zakładem karnym w systemie dozoru elektronicznego są mierzalne i uwidocznione w tabeli 7. Od 1 września 2009 roku, kiedy to weszła w życie ustawa z dnia 7 września 2007 roku, z roku na rok wzrastała liczba wykonywanych kar pozbawienia wolności poza zakładem karnym w systemie dozoru elektronicznego aż do 30 czerwca 2015 roku. Od 1 lipca 2015 roku orzekanie kary w tym systemie już było niemożliwe - była wykonywana, tylko gdy została wcześniej orzeczona. Na początku drugiego kwartału 2016 roku przywrócono orzekanie wykonywania kary w systemie dozoru elektronicznego. $Z$ początku następuje wzrost wykonywania kary w tym systemie do około $6 \%$.

Należy stwierdzić, że następuje zmniejszenie populacji więziennej. Jest to zjawisko pozytywne, gdyż tą drogą zwiększa się powierzchnia celi mieszkalnej, w której egzystuje skazany, a zmniejsza się współczynnik prizonizacji. Nie jest jednak w drugim etapie wykorzystana pojemność systemu dozoru elektronicznego. Na dzień 30 kwietnia 2017 roku była wykorzystana tylko w $31,1 \%$ (wykres 1 ). Odpowiedź na drugie pytanie jest o wiele trudniejsza. Dozór elektroniczny może ograniczać liczebność populacji więziennej w sposób bezpośredni (SDE) oraz pośredni (jako obowiązek nałożony na skazanego w związku z karą ograniczenia wolności, jako środek karny i zabezpieczający) ${ }^{16}$. Zwiększenie możliwości stosowania zakazów i środków zabezpieczających może zapobiec powrotowi do przestępstwa i zasileniu systemu więziennego. Nowelizacja ustawą z dnia 20 lutego 2015 roku zakładała rozbudowanie i zwiększenie stopnia dolegliwości kary ograniczenia wolności. Ten zabieg był bardzo interesujący przede wszystkim dlatego, że mógł skłaniać sąd do częstszego sięgania po tę karę zamiast po kary izolacyjne.

16 Dz.U. z 2016 r., poz. 428. 


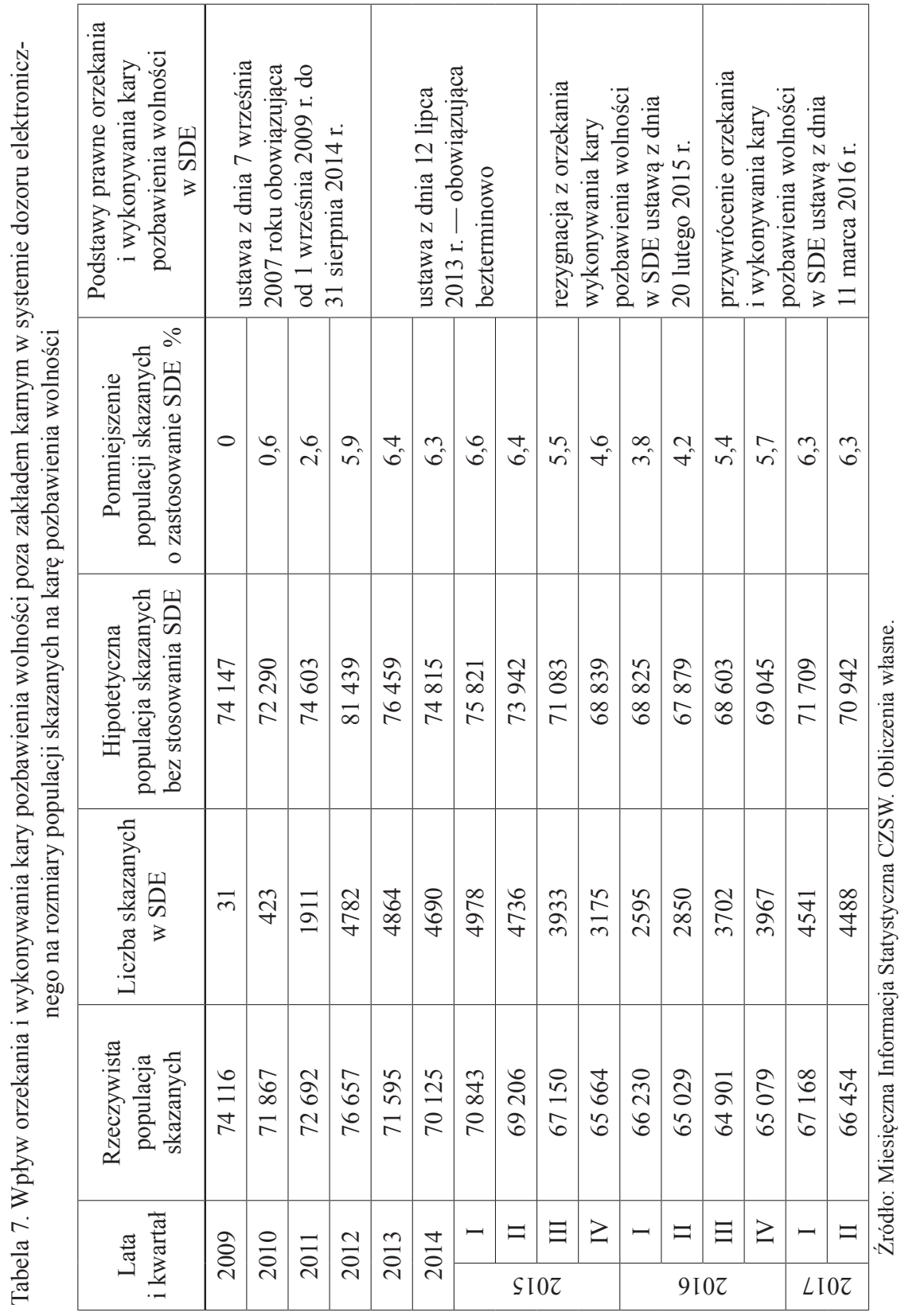


Częstsze stosowanie kar wolnościowych owocowałoby redukcją populacji więziennej. Przepis mówiący o tym, że kara ograniczenia wolności polega między innymi na obowiązku pozostawania w miejscu stałego pobytu lub innym wyznaczonym miejscu z zastosowaniem systemu dozoru elektronicznego (art. $34 \S 1$ a pkt. 2 k.k.) został uchylony po ponad dziewięciu miesiącach stosowania ustawą z dnia 11 marca 2016 roku o zmianie ustawy - Kodeks karny oraz ustawy — Kodeks karny wykonawczy ${ }^{17}$. Derogacji tego przepisu dokonano bez oceny przyczyn niestosowania go $\mathrm{w}$ takim stopniu, w jakim oczekiwano. Wykonywanie kary pozbawienia wolności poza zakładem karnym w systemie dozoru elektronicznego ma wpływ na zmniejszenie populacji więziennej, ale to nie jest argument wystarczający, aby mu przypisać szczególną rolę w polityce karnej. Walory takiego nieizolacyjnego sposobu wykonywania kary pozbawienia wolności są bezsporne, lecz bardziej racjonalną i korzystną, naturalną alternatywą wobec kar krótkoterminowych pozbawienia wolności powinna być przede wszystkim grzywna i kara ograniczenia wolności. Pojemność 15 tys. miejsc w SDE można wykorzystać w innych ważnych celach, które są istotne dla polityki kryminalnej, w tym karnej państwa.

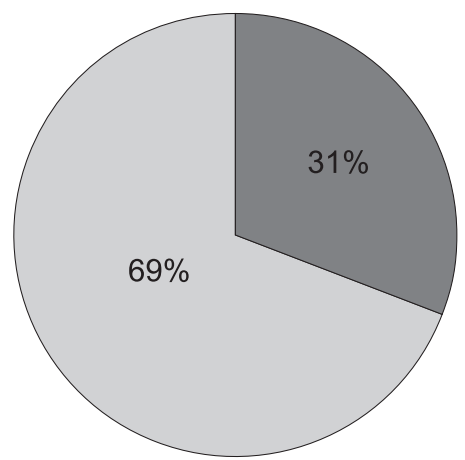

liczba skazanych 4666

liczba miejsc wolnych w SDE 10334

Wykres 1. Wykorzystanie systemu dozoru elektronicznego w stosunku do możliwości.

Stan na 30 kwietnia 2017 roku. Pojemność systemu — 15 tys. miejsc

17 A. Nawój-Śleszyński, Funkcje i rola systemu dozoru elektronicznego w znowelizowanym kodeksie karnym przez ustawe z dnia 20 lutego 2015 r., [w:] Przyszłość polskiego prawa karnego. Alternatywne reakcje na przestęsstwo, red. S. Pikulski, W. Cieślak, M. Romańczuk-Grącka, Olsztyn 2015, s. 408-419.

Nowa Kodyfikacja Prawa Karnego 48, 2018

(C) for this edition by CNS 


\section{Podsumowanie i wnioski}

Jednym z podstawowych celów nowelizacji systemu prawa karnego ustawą z dnia 20 lutego 2015 roku było zmniejszenie populacji osób skazanych na karę pozbawienia wolności. Chodziło o redukcję populacji więziennej, która odbywa zasadniczą karę pozbawienia wolności i zastępczą karę pozbawienia wolności. Jednym z ważnych sposobów osiągania tego celu była zmiana struktury orzekanych kar kryminalnych na taką, w której przeważałyby kary nieizolacyjne. Taka strategia polityki karnej przełożyłaby się na zmniejszenie udziału tej grupy osób pozbawionych wolności w populacji więziennej. Upłynął już odpowiedni czas, który powinien pozwolić na ocenę efektów znowelizowanego prawa karnego. Na podstawie statystyk należy stwierdzić, że przez półtora roku stosowania znowelizowanego prawa karnego nastąpiły korzystne zmiany w zakresie orzekania przez sądy pierwszej instancji kar kryminalnych. W roku 2015 i 2016 w stosunku do roku 2014 następuje wzrost liczby orzekanych kar nieizolacyjnych o $25,8 \%$; spadek liczby orzeczeń kary pozbawienia wolności z warunkowym zawieszeniem jej wykonania o 29,3\%. Niepokoić może jedynie wzrost o 2,8\% orzeczonych kar bezwzględnego pozbawienia wolności. W strukturze kar nieizolacyjnych orzeczonych przez sądy rejonowe bardzo wyraźnie wzrosła liczba orzeczonej kary grzywny samoistnej, bo o 33,5\%. W populacji więziennej, w której skład wchodzi grupa skazanych na karę pozbawienia wolności, tymczasowo aresztowani i ukarani w okresie dwóch lat od 1 lipca 2015 roku do 30 czerwca 2017 roku spada z kwartału na kwartał odsetek skazanych na zasadniczą karę pozbawienia wolności. Spadek ten jest wyraźny w grupie skazanych na karę pozbawienia wolności - wynosi 3\% do okresu wyjściowego. Przeciwne zjawisko występuje w grupie skazanych na zastępczą karę pozbawienia wolności (wzrost o 1,6\%). Ta grupa powiększa się z kwartału na kwartał analizowanego okresu. Od 2016 roku następuje wzrost liczebności grupy tymczasowo aresztowanych w populacji więziennej, który ma wpływ na wielkość i tendencje rozwojowe współczynnika prizonizacji w Polsce. W populacji więziennej zmniejszyła się w niewielkim stopniu grupa skazanych z wymiarem kary do 5 lat. W tej grupie nastąpił wzrost najkrótszych kar krótkoterminowych do 6 miesięcy. Spadek wykonywanych kar krótkoterminowych w wymiarze od 6 miesięcy do 2 lat 
miał wpływ ostatecznie na ogólną tendencję spadkową rozmiarów populacji skazanych na kary do 5 lat. Niewielka, malejąca tendencja orzekania kar krótko- i średnioterminowych jest następstwem polityki karnej, w której nie został wykorzystany potencjał redukcji populacji skazanych na karę pozbawienia wolności, tkwiący w największym stopniu w tym obszarze wymierzanych kar kryminalnych.

Podsumowując ocenę skutków związanych z wprowadzeniem zmian ustawą z dnia 20 lutego 2015 roku, należy stwierdzić, że w polityce karnej zostały osiągnięte $\mathrm{w}$ pewnym stopniu korzystne zmiany. Zmieniła się struktura orzekanych kar kryminalnych, w której przeważają kary nieizolacyjne. Struktura orzekanych kar nie przełożyła się na znaczącą redukcję populacji skazanych na karę pozbawienia wolności. Kary krótko- i średnioterminowe stanowią ponad $80 \%$ wszystkich skazań na karę pozbawienia wolności. Istnieje jednak nadzieja, że ta tendencja, dalsza i większa redukcja tych kar, nastąpi w niedługiej przyszłości, pod warunkiem że w polityce karnej będzie kontynuowany kierunek, który już podjęto. Jeżeli nie, to może się pojawić zjawisko wzrostu współczynnika prizonizacji, który już wzrósł z 184,1 w 2015 roku do 186,1 w 2016 roku. $\mathrm{Na}$ podstawie danych statystycznych pierwszego półrocza 2017 roku można prognozować, że jeszcze wzrośnie za przyczyną zwiększenia się liczby tymczasowo aresztowanych w populacji więziennej.

Zmiany w polityce karnej są następstwem nie tylko zmian normatywnych prawa, lecz przede wszystkim zmian mentalnych i motywacyjnych osób je stosujących. Takie zmiany wymagają jednak czasu. Dotychczasowe doświadczenia w tym zakresie nie są zbyt optymistyczne.

\section{Prison population in Poland after the amendment of the criminal law system by the act of 20 February 2015}

\section{Summary}

The article discusses the questions of aims and consequences of the change of the criminal law system of 20 February 2015. One of the basic aims of the amendment was to reduce the amount of prisoners sentenced to imprisonment. One of the ways to achieve this aims has been to change the structure of the criminal system with non-freedom-lose penalties. The amended Criminal Law works for two years. 
Based on the analysis of the statistical data, it was found that during the period under review, from 1 July 2015 to 30 June 2017, the structure of imposed penalties by the court has been favorably changed. There was a 33,5\% reduction in imprisonment and a $29,3 \%$ reduction of suspended sentences. The unfavorable phenomenon is the increase of the sentences of imprisonment with the absolute execution at 2,8\%. Favorable and expected changes in the structure of the penalties imposed did not transfer significantly into the reduction of the population sentenced to imprisonment. In 2015 was the imprisonment rate at 184.1, and in 2016 it rose to 186.4. The reason for this was the increase in temporarily detained persons in the prison population.

Keywords: reform of criminal law, structure of criminal penalties, prison population, reduction of the prison population. 